Available online at GSC Online Press Directory

GSC Biological and Pharmaceutical Sciences

e-ISSN: 2581-3250, CODEN (USA): GBPSC2

Journal homepage: https://www.gsconlinepress.com/journals/gscbps

(RESEARCH ARTICLE)

\title{
Effects of environmental parameters on the nycthemeral migratory behaviour of copepod species in the Al Massira reservoir, Morocco
}

\author{
Khadija Mokhliss ${ }^{1, *}$ and Mohammed Moncef ${ }^{2}$ \\ ${ }^{1}$ Laboratory of Physiology and Ecotoxicology, Department of Biology, Faculty of Sciences Chouaïb Doukkali University, \\ 2400, BP 20, Route Ben Maachou, El Jadida, Morocco. \\ ${ }^{2}$ Laboratories of Environmental Study and Analysis, Department of Biology, Faculty of Sciences Chouaïb Doukkali \\ University, 2400, BP 20, Route Ben Maachou, El Jadida, Morocco.
}

Publication history: Received on 23 November 2020; revised on 12 December 2020; accepted on 15 December 2020

Article DOI: https://doi.org/10.30574/gscbps.2020.13.3.381

\begin{abstract}
To improve our knowledge of nocturnal and diurnal migratory activity in copepods and in order to assess the effect of abiotic parameters on this activity, we have undertaken at the level of the Al Massira dam reservoir (dam located on the wadi Oum Erbia, in Morocco) the monitoring of the migration of the main species, during a 24-hour nycthemeral cycle. To be done; the measurement and sampling step is carried out every 4 hours; at different depths of the prospected station. The temperature, $\mathrm{pH}$, dissolved oxygen and chlorophyll $a$ measurements are taken. The systematic position of the main species of copepods and their density are determined.

Most of the results obtained show that the main species of copepods inventoried within the reservoir are Neolovenula alluaudi and Acanthocyclops robustus. The nauplii of these two species present the maximum of densities at a depth of $5 \mathrm{~m}$ at $12 \mathrm{~h}$; i.e. 70400 individual / $\mathrm{m} 3$ (ind / $\mathrm{m}^{3}$ ). The development stages of $N$. alluaudi are preferentially concentrated at $-2 \mathrm{~m}$ at midnight, with 1900 ind / $\mathrm{m}^{3}$, while at $12 \mathrm{~h}$ and $16 \mathrm{~h}$ this density is less than 500 ind / $\mathrm{m}^{3}$. The maximum density for the stages of $A$. robustus is noted at midnight on the surface (at $-5 \mathrm{~m}$ ), i.e. 3400 ind / $\mathrm{m}^{3}$ for C1-2 and 3200 ind / $\mathrm{m}^{3}$ for stages C3-4-5 at $-2 \mathrm{~m}$ at the same time. Therefore, the migratory behavior of these species seems to depend on the temperature, the concentration of dissolved oxygen and the variation of the food during the different phases of the cycle.
\end{abstract}

Keywords: Nycthemeral migration; Copepods; Dam; Abiotic parameters

\section{Introduction}

Zooplankton migration is a phenomenon observed in many marine and freshwater species. The classic pattern of these migrations consists of a rise in the upper layers at dusk, with a maximum surface density around midnight. Some authors observe a bimodal rhythm with a descent to the deep layers in the middle of the night and at dawn [1, 2]. Most of the studies carried out on these mechanisms consider that environmental factors induce these migratory movements. Indeed, the authors have demonstrated the presence of a relationship between temperature, dissolved oxygen, chlorophyll $a$ content and migration [3]. The effect of predation [4] and the influence of hydrological and hydrodynamic factors on the migratory behavior of certain zooplankton species Berge et al. [5] have also aroused the interest of the authors.

\footnotetext{
* Corresponding author: Khadija Mokhliss

Laboratory of Physiology and Ecotoxicology, Department of Biology, Faculty of Sciences Chouaïb Doukkali University, 2400, BP 20, Route Ben Maachou, El Jadida.
}

Copyright (C) 2020 Author(s) retain the copyright of this article. This article is published under the terms of the Creative Commons Attribution Liscense 4.0. 
At the national level, researchers have studied the migration of zooplankton, particularly in lagoon and estuarine environments [6, 7]. At the level of the Al Massira dam reservoir, no study has been carried out on this subject. The objective of this work is on the one hand to study the nycthemeral migration of two species of copepods that are the most representative of the environment and on the other hand to study the effect of environmental factors on this migratory behavior. The ultimate goal of this study is to understand the mechanism of this ecosystem of great water interest.

\section{Material and methods}

\subsection{Study site}

The Al Massira reservoir was filled in February 1979 and is considered the centerpiece of the development plan for the watershed of the Oum Er Rbia wadi. It is located in the province of Settat, $120 \mathrm{~km}$ south-east of Casablanca (Fig. 1).

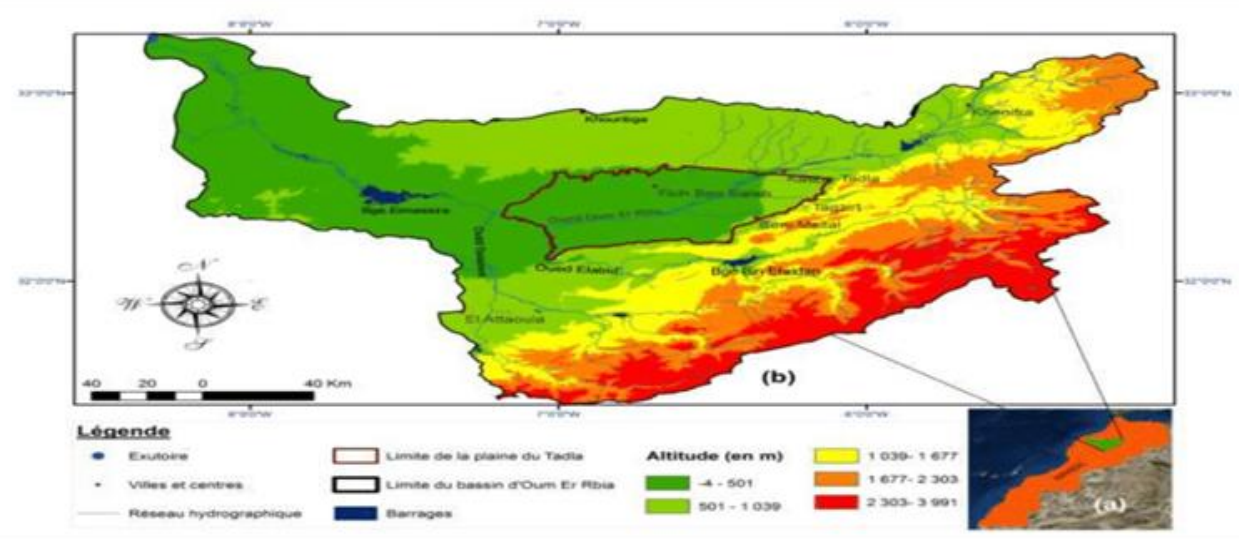

Figure 1 Oum Er Rbia river

The main characteristics of the reservoir are given in Table 1.

Table 1 Morphometric characteristics of the Al Massira reservoir.

\begin{tabular}{|l|l|}
\hline Parameters & Values \\
\hline Watershed area & $28.5 \mathrm{~km}^{2}$ \\
Maximum depth & $40 \mathrm{~m}$ \\
Average depth & $20 \mathrm{~m}$ \\
Length & $30 \mathrm{Km}$ \\
Width & $10 \mathrm{Km}$ \\
Volume & $280.106 \mathrm{~m}^{3}$ \\
\hline
\end{tabular}

The coordinates are $32^{\circ} 28^{\prime} 32^{\prime \prime}$ north and $7^{\circ} 32^{\prime} 15^{\prime \prime}$ west. The atmospheric temperature is $18.5^{\circ} \mathrm{C}$ at 8 p.m. The water resources of the Oum Er Rbia wadi watershed are on the one hand from surface origin from three large wadis and on the other hand from groundwater from water tables.

\subsection{Sampling}

The water and zooplankton samples are sampled at the deepest point of the reservoir (Fig. 2), located between -35 and $-40 \mathrm{~m}$. 


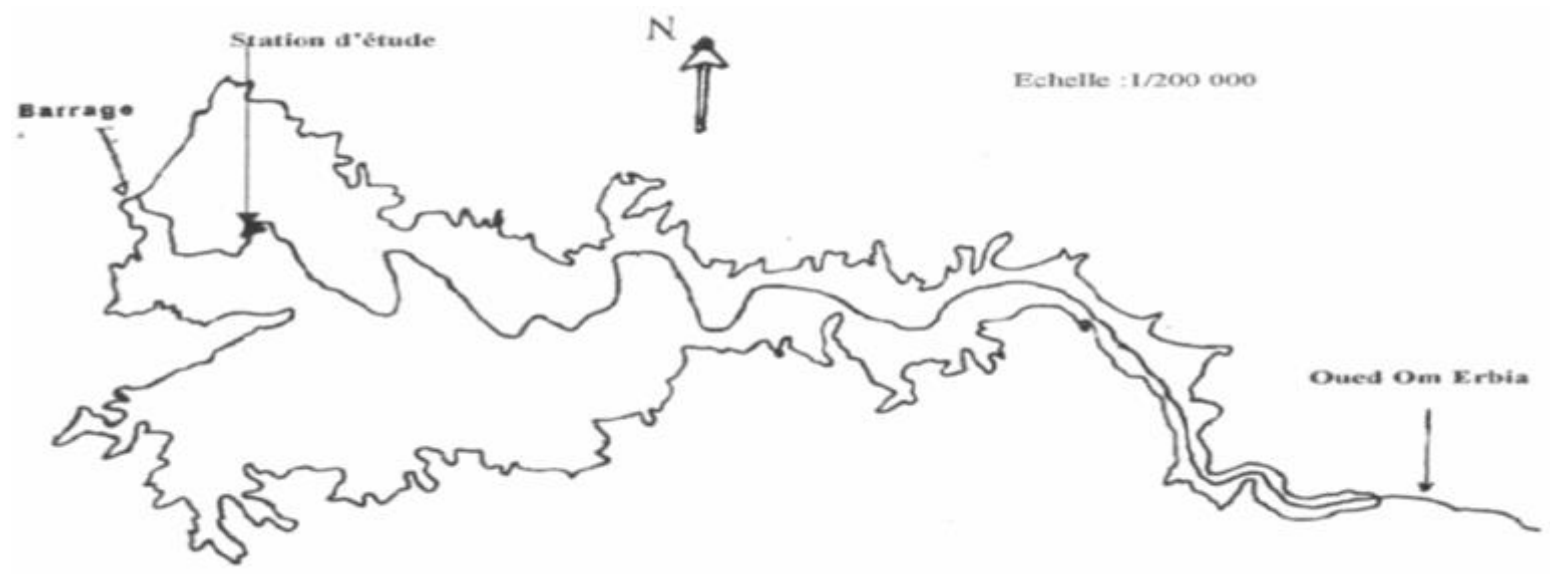

Figure $2 \mathrm{Al}$ Massira reservoir morphology and sampling station.

Samples were collected every four hours during a 24 hour cycle. The different depths are: $-0.2 \mathrm{~m} ;-2 \mathrm{~m} ;-5 \mathrm{~m} ;-10 \mathrm{~m} ;-15$ $\mathrm{m} ;-20 \mathrm{~m} ;-25 ;-30 \mathrm{~m}$ and $-35 \mathrm{~m}$. Samples are taken using a sealing bottle with a capacity of $2.5 \mathrm{l}$, at the rate of 4 samples per depth. A total volume of 10 liters of water is filtered through an $80 \mu \mathrm{m}$ mesh vacuum cloth.

\subsection{Physico-chemical parameters}

The parameters measured in the water at the different depths of the study station are:

- The temperature, measured with an ordinary thermometer, graduated to $1 / 10$ th.

- $\quad$ The $\mathrm{pH}$, measured in situ using a WTW type pH meter, to 1 / 10th of a unit.

- Dissolved oxygen, evaluated by the volumetric method of Winkler. The fixation of the 02 is carried out in the field as soon as the sample is taken and is carried out according to the method of Rodier [8].

\subsection{Chlorophyllian pigments}

Chlorophyll $a$ contents are measured in water at depths of 5 and $15 \mathrm{~m} .0 .5 \mathrm{~L}$ samples are filtered using a glass microfiber filter (GF / C). The contents are determined from the equation of Lorenzen [9] and are expressed in $\mathrm{mg}^{\circ} \mathrm{m}^{3}$.

\subsection{Counting zooplankton}

After sampling and filtering the water from the different depths, the biological samples are immediately fixed in a $4 \%$ formalin solution. In the laboratory, the samples are stained with Rose Bengal and observed under a binocular magnifying glass at high magnification (x 50). The counting is carried out on a Dolffus tank after homogenization in a $10 \%$ glycerin alcohol solution. Enumeration of copepods included nauplii (N), copepodites (C) and adults. For nauplii, this count is made from N1 to N6, all stages combined. For the copepodites, in order to minimize possible errors of identification, we have grouped stages $\mathrm{C} 1$ and $\mathrm{C} 2$ on the one hand and C3, C4 and C5 on the other. The enumeration in adults is carried out in males, non-ovigerous females and ovigerous females of all the species encountered.

\section{Results and discussion}

\subsection{Physico-chemical parameters}

The vertical profiles of the temperatures recorded (Fig. 3) show a certain variation in the thermal gradient of the water column during the cycle. The thermal difference between the bottom and the surface does not exceed $4{ }^{\circ} \mathrm{C}(20.5$ and 17 ${ }^{\circ} \mathrm{C}$ at $24 \mathrm{~h}$ ) at night and $6.5^{\circ} \mathrm{C}$ during the day (22 and $17^{\circ} \mathrm{C}$ at noon). 
A
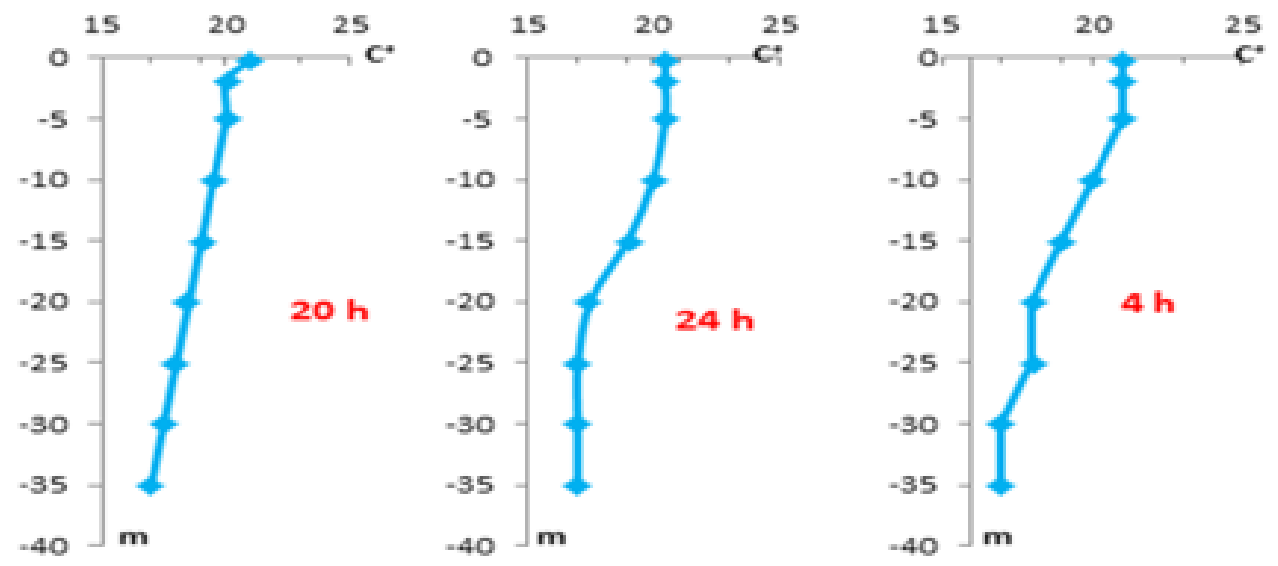

B
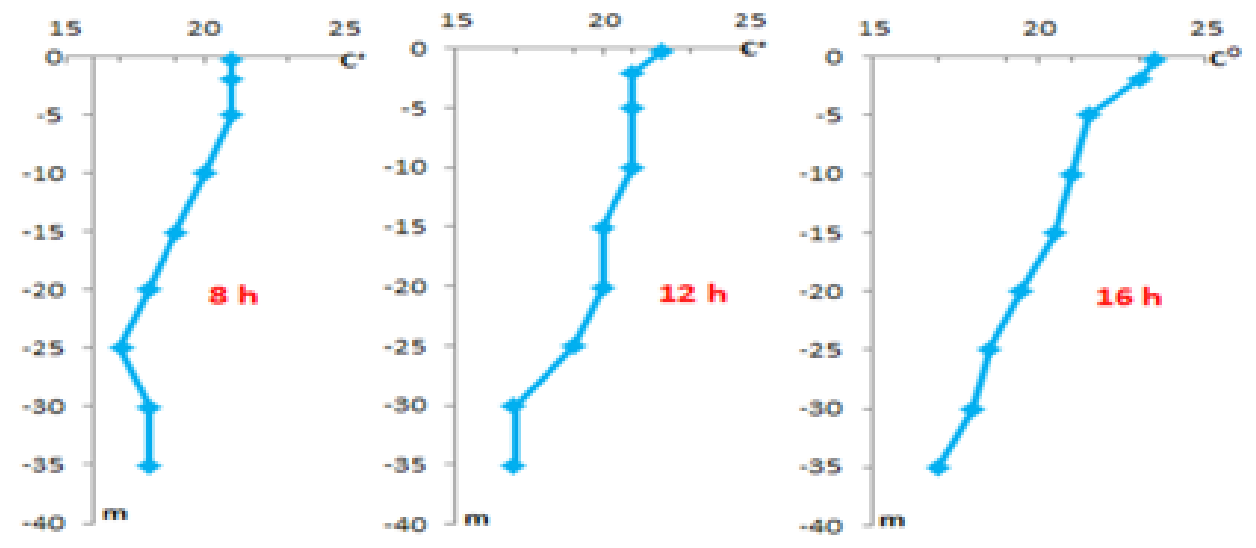

C

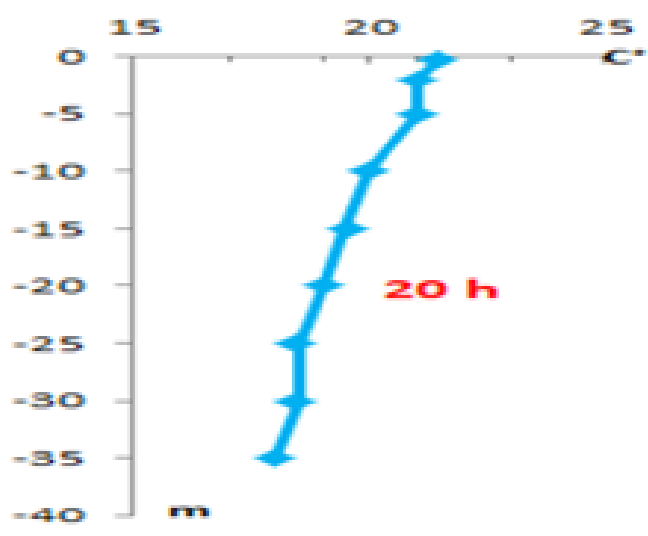

Figure 3 Distribution of temperature during the nycthemeral cycle. $(\mathrm{A}=$ distribution of Temperature during the night of nycthemeral cycle; $\mathrm{B}=$ distribution of Temperature during the day of nycthemeral cycle; $\mathrm{C}=$ vertical temperature profiles to complete the 24 hour cycle).

The $\mathrm{pH}$ values do not show any significant variation between the surface and the bottom. They do not exceed one unit during the whole nycthemeral cycle (Fig. 4). The most marked variations are 7.5 to $-5 \mathrm{~m}$ and 8.5 to $-10 \mathrm{~m}$, recorded at 4 p.m. 
A
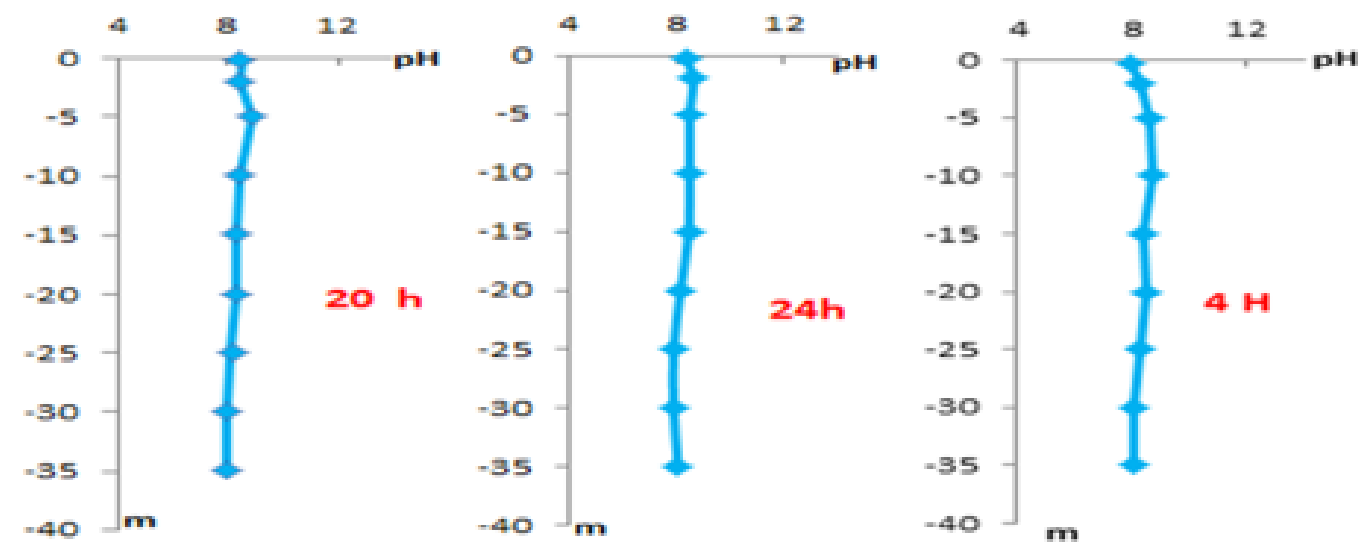

B
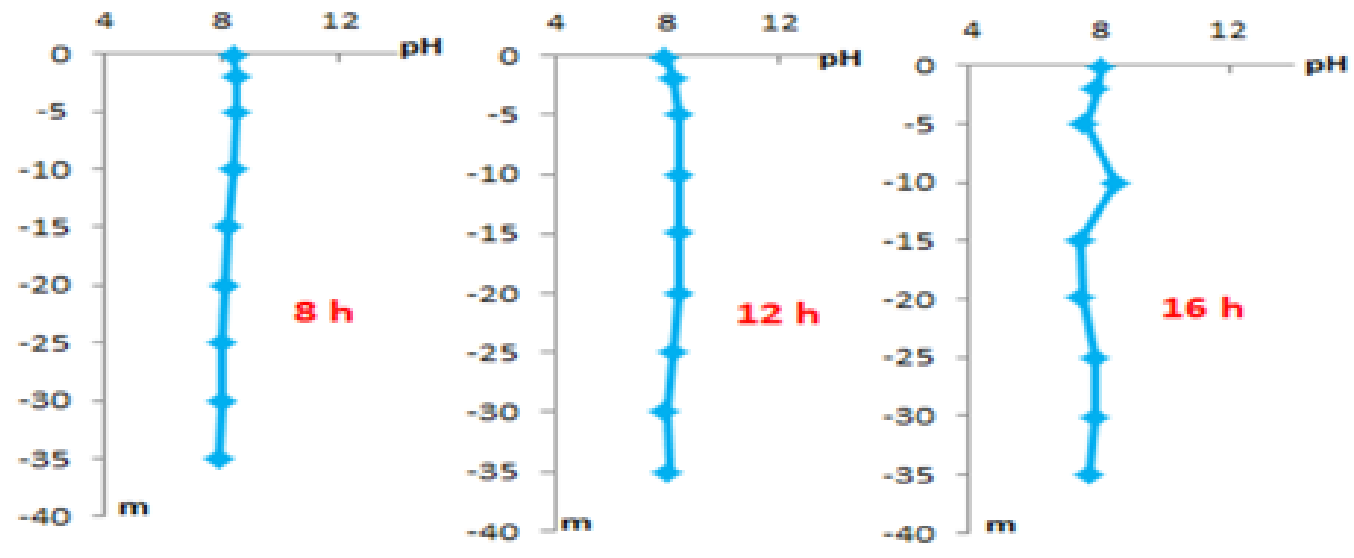

C

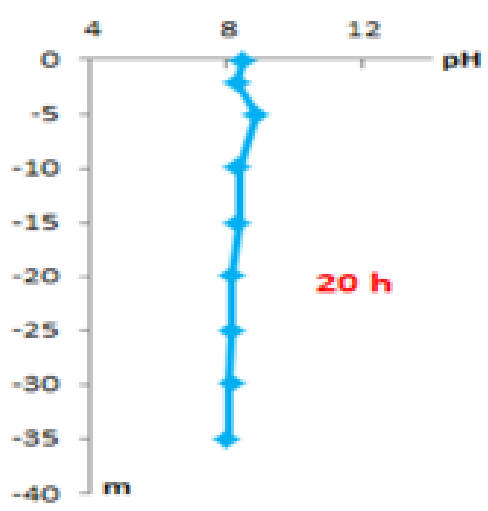

Figure 4 Distribution of $\mathrm{pH}$ during the nycthemeral cycle $(\mathrm{A}=$ Distribution of $\mathrm{pH}$ during the night of nycthemeral cycle; $\mathrm{B}=$ Distribution of $\mathrm{pH}$ during the day of nycthemeral cycle; $\mathrm{C}=$ vertical $\mathrm{pH}$ profiles to complete the 24 hour cycle)

The dissolved oxygen contents are mainly noted between the bottom and the surface (Fig. 5). The maximum and minimum values are respectively $10.4 \mathrm{mg} / .1 \mathrm{lat}-2 \mathrm{~m}$ and $3.7 \mathrm{mg} / .1$ at $-35 \mathrm{~m}$, respectively at $20 \mathrm{~h}$ and at $12 \mathrm{~h}$. 
A
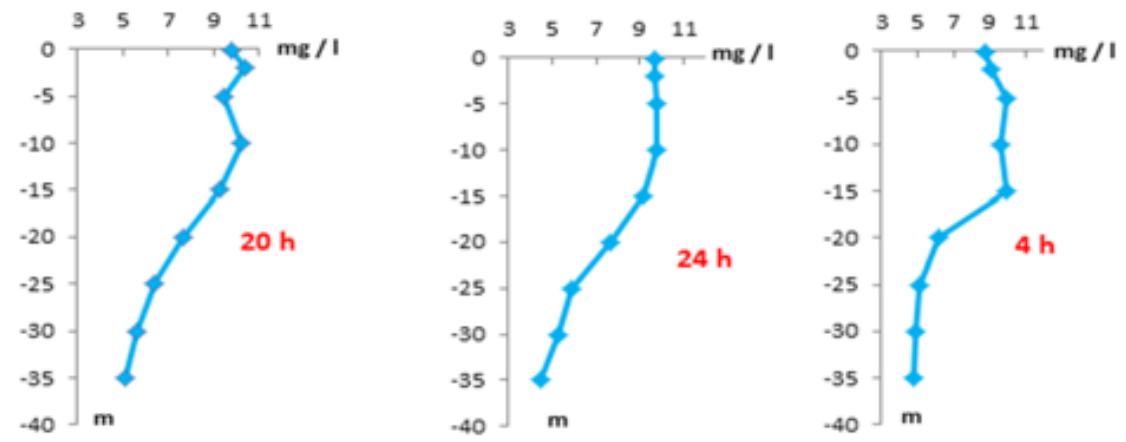

B
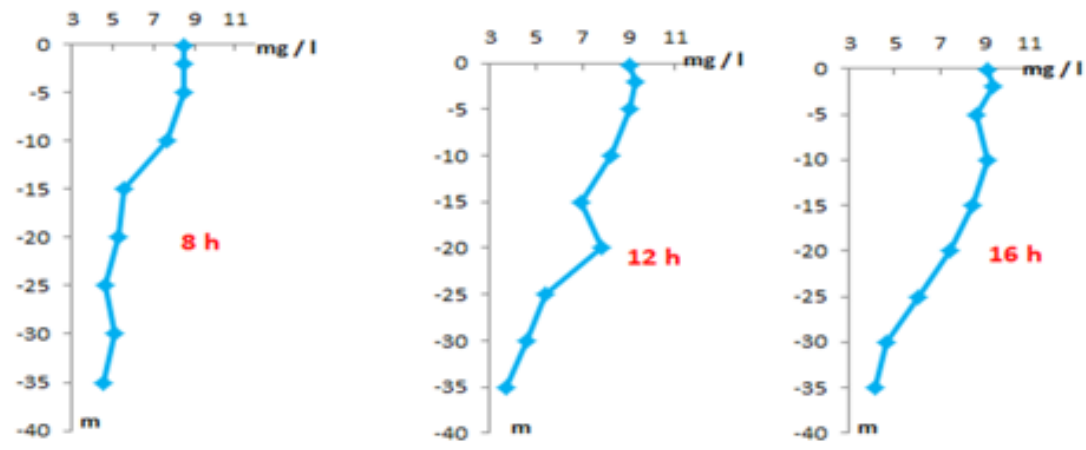

C

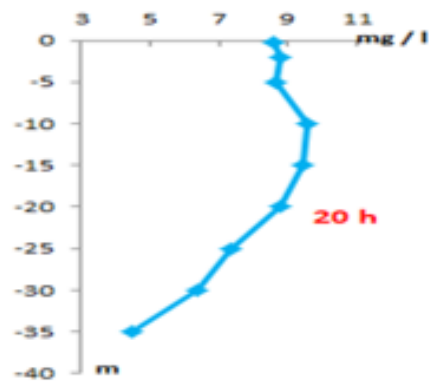

Figure 5 Distribution of dissolved 02 concentration during the nycthemeral cycle. $(\mathrm{A}=$ Distribution of dissolved 02 during the night of nycthemeral cycle; $\mathrm{B}=$ Distribution of dissolved 02 during the day of nycthemeral cycle; $\mathrm{C}=$ vertical dissolved 02 profiles to complete the 24 hour cycle).

\section{2. Chlorophyllian pigments}

The chlorophyll a contents were measured at a depth of 5 and $15 \mathrm{~m}$; the results are reported in Fig. 6. The maximum concentration is $8.87 \mathrm{mg} / \mathrm{m}^{3}$ at $12 \mathrm{~h}$ and the minimum is $1.72 \mathrm{mg} / \mathrm{m}^{3}$ at $4 \mathrm{~h}$; respectively at -5 and $-15 \mathrm{~m}$.

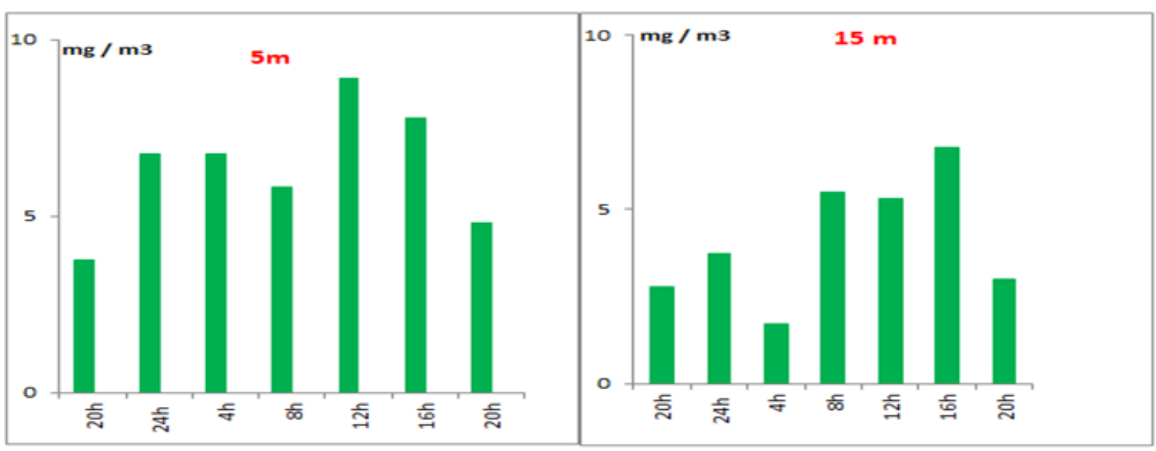

Figure 6 Nycthemeral variation of chlorophylle a, at 5 and 15m. 


\subsection{Zooplankton density Neolovenula alluaudi}

The main species of copepods encountered during the study cycle are: Acanthocyclops robustus and Tropocyclops prasinus. Night-time migration was monitored for the most representative species, in particular $A$. robustus and $N$. alluaudi. The nauplii of these species are well represented and occupy the layers of water located between the surface and $-30 \mathrm{~m}$ (Fig. 7). The maximum number is noted at $-5 \mathrm{~m}$, or 70400 ind $/ \mathrm{m}^{3}$ at $12 \mathrm{~h}$. At a depth of $35 \mathrm{~m}$, the densities are very low to zero.

A
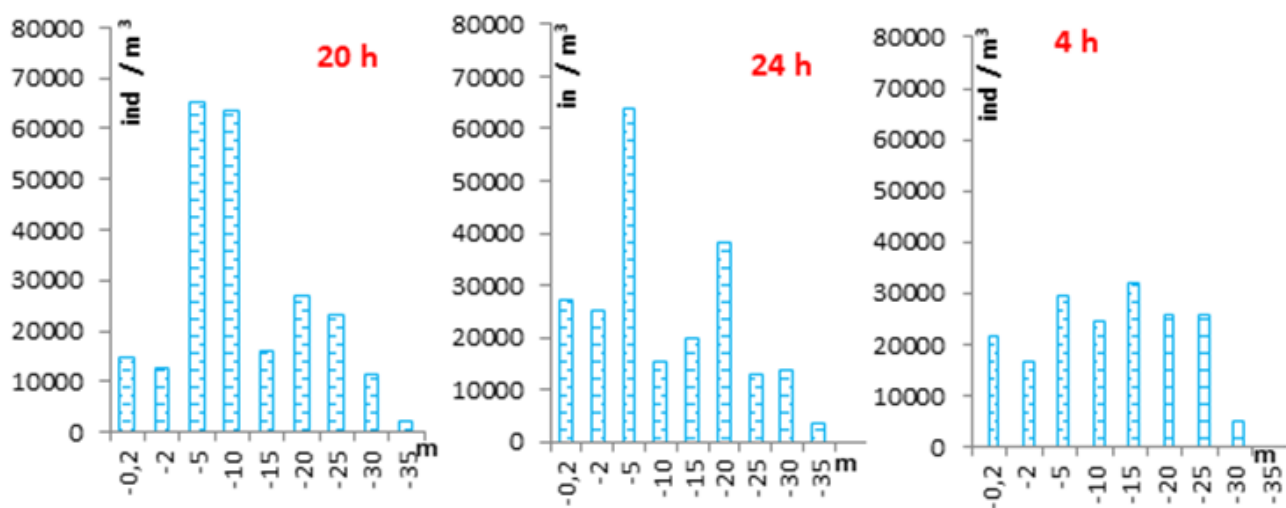

B
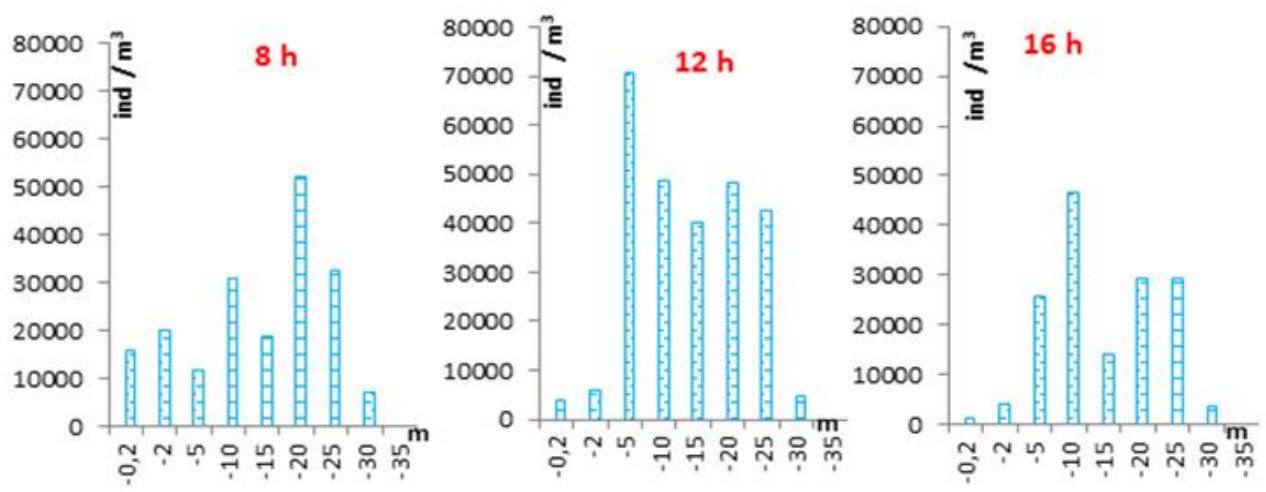

C

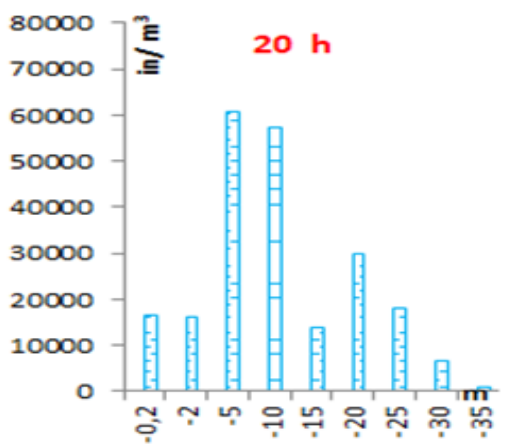

Figure 7 Abundance of nauplii during the nycthemeral cycle. $(A=$ Abundance of nauplii during the night of nycthemeral cycle; $B=$ Abundance of nauplii during the day of nycthemeral cycle; $C=$ Abundance of nauplii at $20 \mathrm{~h}$, to complete the 24 hour cycle.) 
The copepodite stages C1-2 and C3-4-5 of the species $N$. alluaudi concentrate between the surface and - $2 \mathrm{~m}$ during the night. The maximum densities are $1900 \mathrm{ind} / \mathrm{m}^{3}$ at $24 \mathrm{~h}$ at the surface and $800 \mathrm{ind} / \mathrm{m}^{3}$ at $4 \mathrm{~h}$ at $-2 \mathrm{~m}$. During the day, these stages mainly colonize the water column $(-5 ;-20) \mathrm{m}$, the highest densities are 1500 ind / $\mathrm{m}^{3}$ for stages C1-2 and 460 ind / $\mathrm{m}^{3}$ for C3-4-5 at 4 p.m. and $5 \mathrm{~m}$ deep. As for the non-ovigerous males and females, they are present in the column $(-0.2 ;-30) \mathrm{m}$ at any time of the cycle. From $-30 \mathrm{~m}$, the densities become low both during the day and at night. On the other hand, ovigerous females exhibit low densities at all depths and at all times of the cycle (Fig. 8).

A
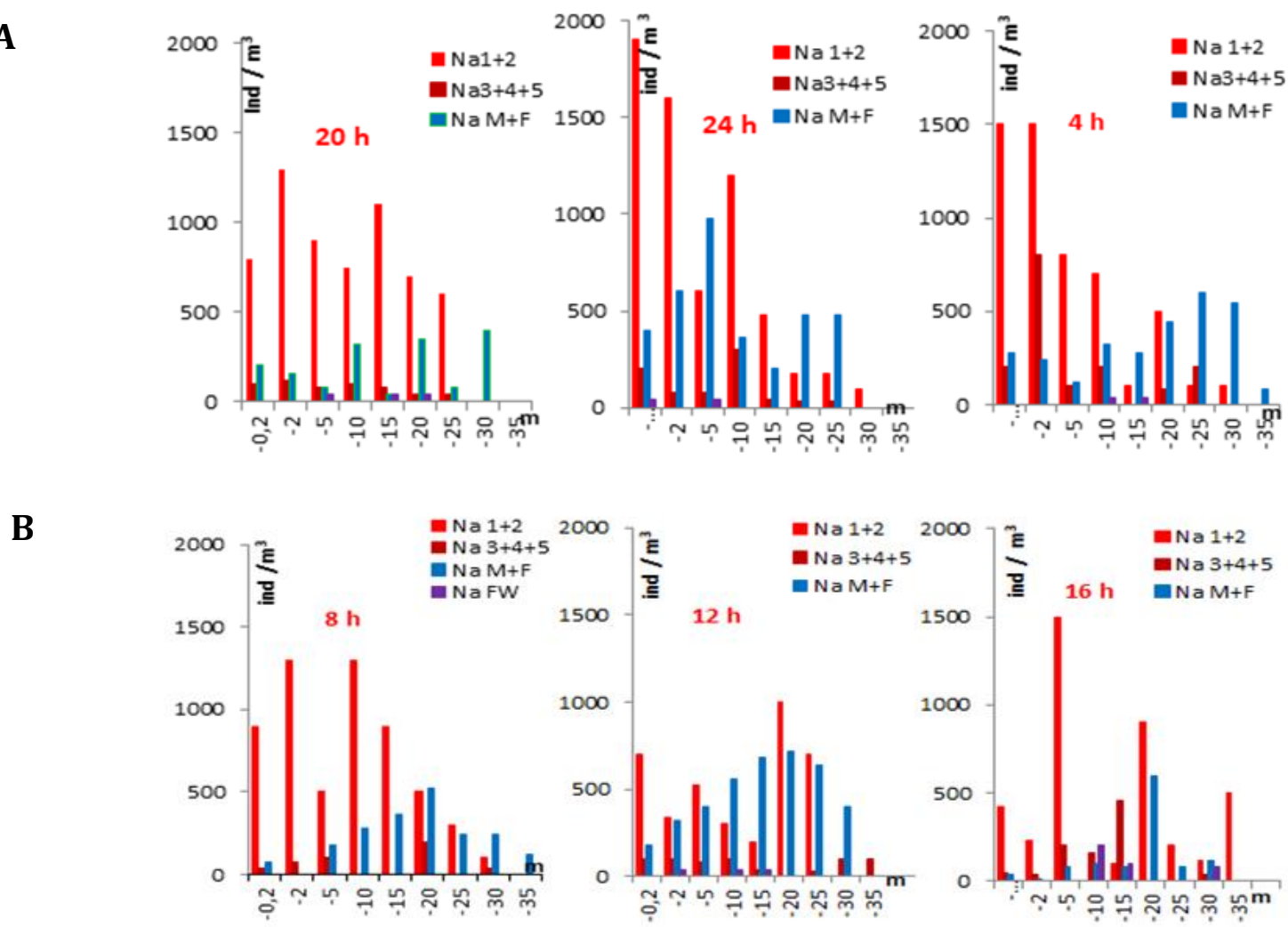

C

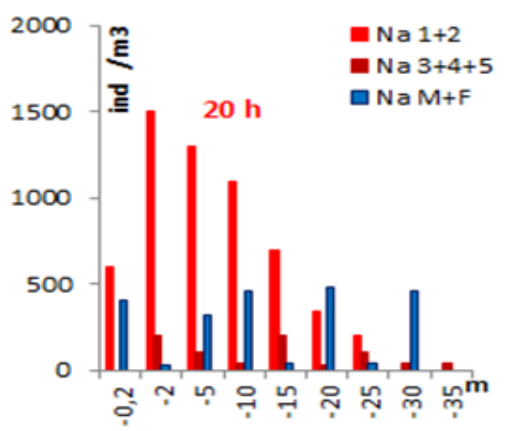

Figure 8 Abundance of Neolovenulla alluaudi during the nycthemeral cycle. (A = Abundance of Neolovenulla alluaudi during the night of nycthemeral cycle; $\mathrm{B}=$ Abundance of Neolovenulla alluaudi during the day of nycthemeral cycle; $\mathrm{C}=$ Abundance of Neolovenulla alluaudi at $20 \mathrm{~h}$, to complete the 24 hour cycle)

During the night, most of the populations of all stages of development of $A$. robustus are concentrated between the surface and $-5 \mathrm{~m}$; i.e. 3400 ind / $\mathrm{m}^{3}$ at $24 \mathrm{~h}$ for C1-2 at $-2 \mathrm{~m}$ and 3200 ind $/ \mathrm{m}^{3}$ at the same time on the surface for C3-45. During the day, these densities are higher in the water column $(-5 ;-20) \mathrm{m}$; i.e. $1000 \mathrm{ind} / \mathrm{m}^{3}$ at $12 \mathrm{~h}$ at $-15 \mathrm{~m}$ for C12 and 4800 ind / $\mathrm{m}^{3}$ for C3-4-5 at $16 \mathrm{~h}$ at the same depth. Adults (males and females) and ovigerous females follow a migratory pattern comparable to that of $N$. alluaudi (Fig. 9). 
A

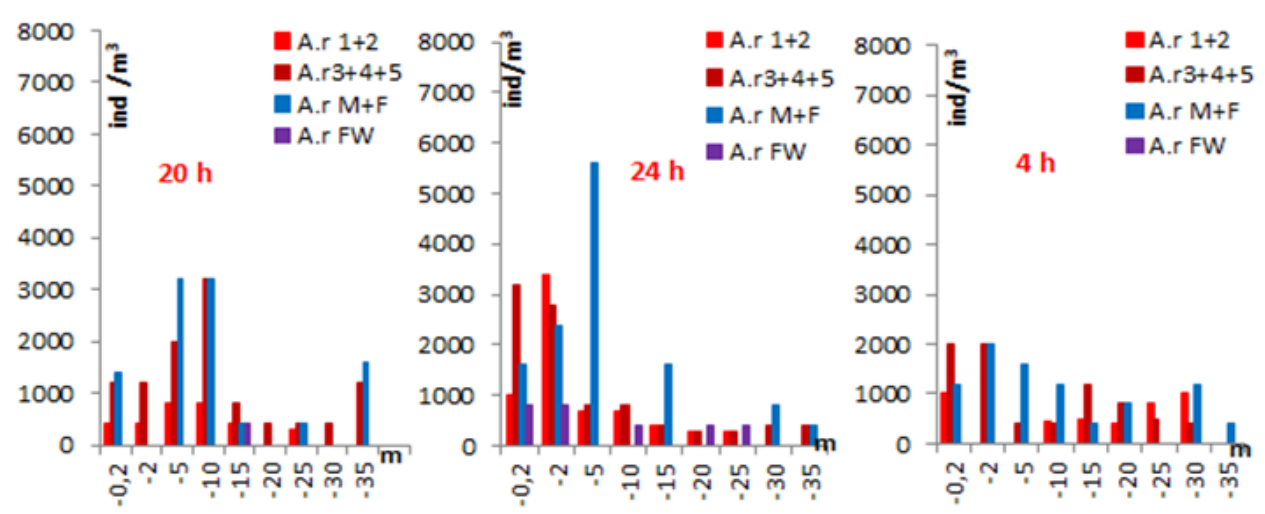

B

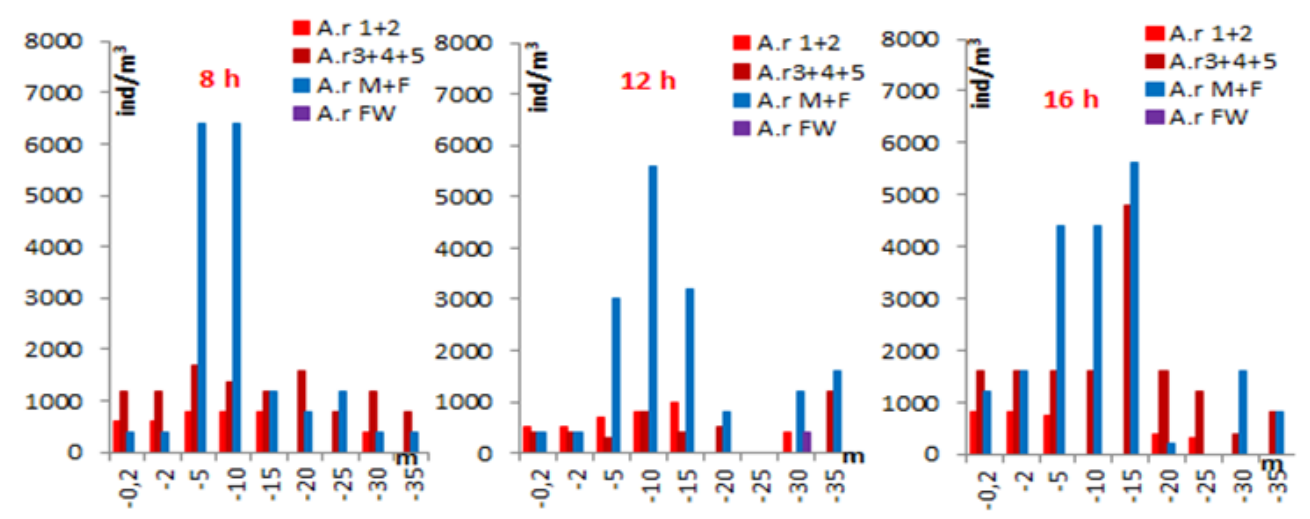

C

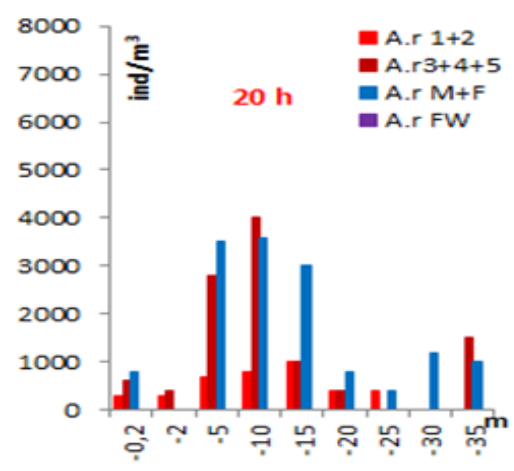

Figure 9 Abundance of Acanthocyclops robustus during the nycthemeral cycle. (A = Abundance of Acanthocyclops robustus during the night of nycthemeral cycle; $\mathrm{B}=$ Abundance of Acanthocyclops robustus during the day of nycthemeral cycle; $\mathrm{C}=$ Abundance of Acanthocyclops robustus at $20 \mathrm{~h}$, to complete the 24 hour cycle.)

PCA's results were reported in (Fig. 10). The analysis has six variables (density, temperature, depth, dissolved 02, $\mathrm{pH}$ and Chlorophyll $a$ ) and two modalities which are depth and sampling time. Axes F1 and F2 respectively present 58\% and $16 \%$ of the information (Fig. $10 \mathrm{~A}$ ) with a total of $74 \%$ of the total variability. The latter is $76 \%, 74 \%$ and $78 \%$ respectively in (Fig. $10 \mathrm{~B}, \mathrm{C}$ and D). At a depth of $2 \mathrm{~m}$, the density of the two copepod species N. alluaudi and A. robustus appears to depend on dissolved oxygen, temperature and chlorophyll $a$. 

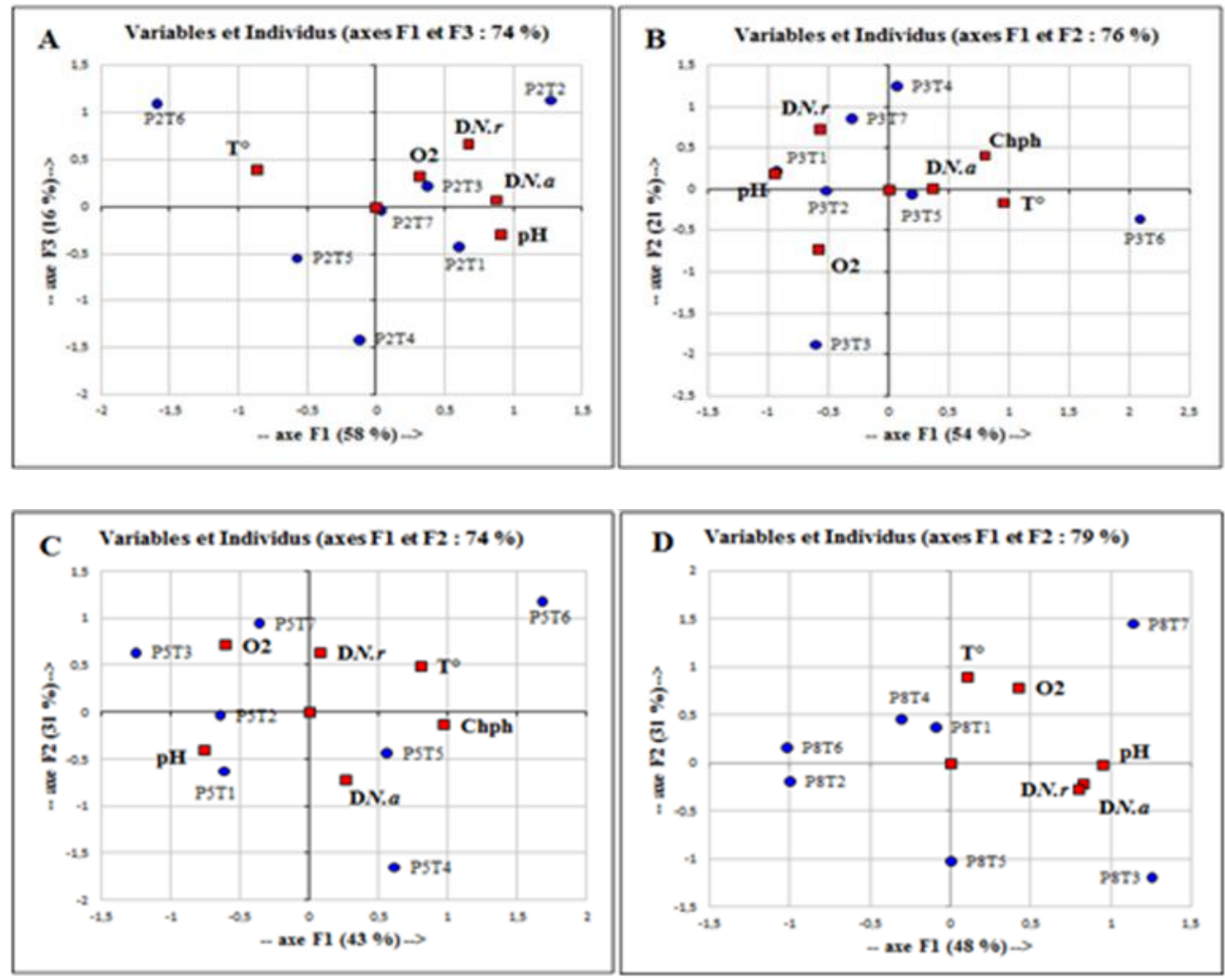

Figure 10 Principal component analysis of the variables (density, temperature, depth, dissolved 02, pH, chlorophyll $a$ ) as a function of time sampling at different depths (A,B,C and D).

Depths in A, B, C and D -2 m (P2); -5 m (P3); -15 m (P5) and -30 m (P7).

Picking time $=20$ h (T1) ; 24 h (T2) ; 4 h (T3) ; 8 h (T4) ; 12 h (T5) ; 16 h (T6) ; 20 h (T7).

It would appear that this difference in migration depends on the physiological state and that each of the stages of development requires different optimal conditions. This has been noted in the copepod Calanus finmarchicus bay Taude [10] and in several other zooplankton species bay Wissel et al. [11]. The density of young people; nauplii and copepodites; is higher compared to that of adults, which could be explained by the strong predation of fish preferentially on young compared to adults [12].

The maximum density of $N$. alluaudi and A. robustus is nocturnal, a situation noted both in the genus Acartia [13] and in other species of copepods and cladocerans $[14,15,16]$. Daylight appears to be the environmental factor that governs copepod migration $[17,18,19,20,21]$; Darkness would protect the visibility of these crustaceans against various predators. The effects of physico-chemical parameters on behavior. The authors have focused on the vertical distribution of zooplankton and on the one hand on the variation in dissolved 02 concentration [22, 23] and on the other hand on a temperature gradient $[24,25,26]$. The nutritional factor was also taken into account in the present study by the evaluation of chlorophyll a. The aphotic zone being poor in phytoplankton consumable by herbivorous zooplankton, the latter would rise to the surface layers during the night to take advantage of the abundance of food [27].

\section{Conclusion}

The study of the nycthemeral cycle carried out in the Al Massira reservoir revealed the migratory activity of the copepods Neolovenula alluaudi and Acanthocyclops robustus, the most represented species in this ecosystem.

Nauplii of these two species show the greatest number at $-5 \mathrm{~m}$ at $12 \mathrm{~h}$. The copepodite stages are concentrated at night, between the surface and - $2 \mathrm{~m}$ or $-5 \mathrm{~m}$; respectively for $N$. alluaudi and A. robustus. The latter has a greater density of these stages.

The adults have the maximum density between -5 and $-10 \mathrm{~m}$ as for that of ovigerous females, it is much lower. 
According to the principal component analysis, the parameters influencing this migratory activity are different depending on the species considered and depend on the water column and the time of the cycle. In fact, the nycthemeral migration of the two species appears to depend mainly on temperature, dissolved oxygen and chlorophyll $a$.

The various stages of development of the same species do not necessarily show the same migratory behavior.

\section{Compliance with ethical standards}

\section{Acknowledgments}

The authors wish to thank the services of the Water Basin Agency of wed Oum Erbia Settat for their fruitful help and availability of data.

\section{Disclosure of conflict of interest}

We have no conflicts of interest to disclose

\section{References}

[1] Mayans M. Etude expérimentale in situ du broutage exercé par le zooplancton (Daphnia longispina) sur le peuplement algal printanier d'une retenue oligotrophe [D.E.A]. Provence, France; 1987.

[2] Pourriot R, Capblanq J, Champ P, Meyer JA. Ecologie du plancton des eaux continentales. Éd. Masson, Paris, France; 1982. P.198.

[3] Ramos-Jiliberto R, Carvajal JL, Carter M, Zúñiga LR. Diel vertical migration patterns of three zooplankton populations in a Chilean lake. Rev Chil de Hist Nat . 2004; 77: 29 - 41.

[4] Taleb H, Lair N, Reyes-Marchant P, Jamet JL. Observation on vertical migrations of zooplankton at four different stations of a small eutrophic, temperate zone lake, in relation to their predators. Arch Hydrobiol Beid Ergebn Limnol. 1993; 39: 199-216.

[5] Berge J, Renaud PE, Darnis G, Cottier F. Arctic complexity: a case study on diel vertical migration of zooplankton. J Plankton Res. 2015; 36 (5): 1279-1297.

[6] El khalki A. Etude du peuplement de Copépodes pélagiques de l'estuaire de l'Oum Er-Rbia: succession saisonnière, dynamiques des populations. Migrations Nycthémérales et impact de la pollution. [Doctorat en Sciences de l'Environnement]. Univ, Chouaïb Doukkali, Faculté des Sciences, El Jadida, Maroc; 2000.

[7] Ouldessaïb T. Etude de peuplement de copépode de la lagune d'Oualidia. [Doctorat de 3ème cycle]. Univ, ChouaïbDoukkali, Faculté des Sciences d’El Jadida; 1997.

[8] Rodier J. L'analyse de l'eau. Éd. Dunod, Paris, France; 1984. P.1365.

[9] Lorenzen NCJ. Determination of chlorophyll and phaeopigments: spectrophotometric esuation. Limnol Oceanogr.1967; 12 (2): 343-346.

[10] Taude KS. An evaluation of factors affecting vertical distribution among recruits of Calanus finmarchicus in three adjacent high latitude localities. Hydrobiologia. 1988; 167: 115-126.

[11] Wissel B, Ramacharan CW. Plasticity of vertical distribution of crustacean zooplankton in lakes with varying levels of water color. J Plankton Res. 2003; 25 (9): 1047-1057.

[12] Zakaria HY, Hussien-Ahmed M, Flower R. Environmental assessment of spatial distribution of zooplankton community in Lake Manzalah. Egypt Acta Adriatica. 2007; 48 (2): 161-172.

[13] Pagano M, Gaudy R, Thibault D, Lochet F. Vertical migration and feeding rythms of mesozooplanktonic organisms in the Rhone river plume areal (North-West Mediterranean sea). Estuarien Coast Shelf Sci. 1993; 37: 251-269.

[14] Balvay G. Ségrégation spatial diurne du zooplancton dans le Leman. Hydroécol App. 1996; 8 (1-2): 143-153.

[15] Cuilin HU, Shengrui W, Longgen G, Ping X. Effects of the proximal factors on the diel vertical migration of zooplankton in a plateau meso-eutrophic Lake Erhai, China. J Limno. 2014; 73 (2): 375-386.

[16] Mokhliss K, Moncef M. Migrations nycthémérales des principales espèces de Cladocères de la retenue Al Massira, Maroc. SMETox Journal. 2018; 1 (2): 137- 147. 
[17] Chowdhury ST, Chattopadhyay J. Mathematical modeling of cascading migration in a tri-trophic food-chain system. J Biol Phys. 2013; 39 (3): 469-487.

[18] Haupt F, Stockenreiter M, Baumgartner M, Boersma M, Stibor H. Daphnia diel vertical migration: implications beyondzooplankton. J Plankton Res. 2009; 31 (5): 515-524.

[19] Lampert W, Taylor BE. Zooplankton grazing in a eutrophic lake: Implication of diel vertical migration. Ecology. 1985; 66: 68-82.

[20] Leising AW, Franks PJS. Copepod vertical distribution within a spatially variable food source: a simple foragingstrategy model. J Plankton Res. 2000; 22 (6): 999-1024.

[21] Williamson CE, Sanders RW, Moeller RE, Stutzman PL. Utilization of substance food resources for zooplankton: Implications for diel vertical migration theory. Limnol Oceanogr. 1996; 41: 224-233.

[22] Bianchi D, Babbin AR, Galbraith ED. Enhancement of anammox by the excretion of diel vertical migrators.PNA. 2014; 111 (44): 15653-15658.

[23] Małgorzata A. Spatial distribution of brood-bearing Females of limnetic species of Cladocera. Comptes Rendus Biologies. 2013; 336 (9): 457-465.

[24] Cooke S, Williamson CE, Leech D, Boeing W, Torres L. Effects of temperature and ultraviolet radiation on diel vertical migration of freshwater crustacean zooplankton. Can J Fish Aquat Sc. 2008; 65: 1144-1152.

[25] Helland IP, Freyho FJ, Kasprzak P, Mehner T. Temperature sensitivity of vertical distributions of zooplankton and planktivorous fish in a stratified lake. Oecologia. 2007; 151 (2): 322-330.

[26] Khalifa N, El-Damhogy KE, Fishar MR, Amr M, Nasef M, Hegab H. Vertical distribution of zooplankton in Lake Nasser. Egypt J Aquat Res. 2015; 41 (2): 177-185.

[27] Mokhliss K, Moncef M, Alaoui L. Étude des variations saisonnières du broutage zooplanctonique sur le peuplement phytoplanctonique de la retenue de barrage Al Massira (Maroc). Hydroécol App. 2001; 2: 175-191. 